\title{
超音波診断装置を用いた肋骨と横隔膜の動きの計測 一呼吸運動の計測を臨床に生かすために一
}

\author{
中 徹 $^{1 \dagger}$, 啸藤 裕 ${ }^{2}$, 萩原早 保 ${ }^{3}$ \\ 1 鈴鹿医療科学大学 保健衛生学部 理学療法学科 \\ 2 心身障害児総合医療療育センターリハビリテーション室 \\ 3 小山田記念温泉病院リハビリテーションセンター
}

要旨 呼吸運動は歩行と同様に律動的な運動ではあるが, 肋骨と横隔膜の複雑な動きで構成されている. 従って呼吸運動を運 動現象学的に測定するには, 三次元動作解析装置や放射線による透視などが必要となる. しかし, これらは設備的な制限, 生 体への侵襲の大きさという点から臨床的利用としては実用性に乏しい。

本解説では，医療機関であれば設置されており，侵襲の少ない超音波診断装置を利用し，体表から簡易的に肋骨と横隔膜の 動きを測定できる方法を提案する. 超音波による測定は横隔膜で二つの方法が報告されているが，肋骨では報告が無い，本解 説では肋骨と横隔膜を直接とらえる手法で得たデータと共に臨床応用できる測定方法を考えていきたい.

キーワード：呼吸運動，肋骨，横隔膜，超音波，姿勢

\section{1. 生体と呼吸}

呼吸は生体維持のために必要な酸素の供給と二酸化炭素 の排出を行う生理的現象であり, 呼吸運動と肺胞でのガス 交換機能からなっている. 呼吸は, 生命維持システムとし ては自律的に制御される一方, 話し声の大きさや抑揚のコ ントロール時は随意的に制御されており, 自律的・随意的 制御が混在した多様なシステムでもある。呼吸を発達的に 見た場合, 肺容積と肺胞数の増加, 運動発達に伴い胁骨が 脊柱に対して斜め下方向に傾斜する経過をとる. それによ り胸郭の可動性が高まり, 一回換気量の増加・胸腹式呼吸 の安定化という呼吸の量・質的な発達が生じてくる.

多様な因子で形成されている呼吸は, 様々な時点, 要因 で制限が生じうる。呼吸の障害は生体へのエネルギー供給 系の不具合であり, 心身の活動性の低下と肥満, 心肺機能 の低下などを惹起し日常生活の制限に繋がることになる. このような背景から, 呼吸改善は重要な課題であるが, そ の前提として呼吸評価について解説したい.

\section{2. 呼吸運動と呼吸機能およびその制限}

呼吸の制限の原因は, 肺や気管支など呼吸に関連する臓 器の不全と, 呼吸関連の運動器の不全に分けられる. 前者 と後者は, 一次的には単独で存在する場合もあるが, 多く の場合は二次的にもう一方の原因も合わさった形で呼吸の 制限が現れる。

\section{1 年 4 月 1 日受付}

${ }^{\dagger} \bar{T} 510-0293$ 三重県鈴鹿市岸岡町 1001 番地 1 鈴鹿医療科学大学保健衛生学部理学療法学科 中 徹

Tel:059-383-8991 Fax:059-383-9666

E-mail:naka@suzuka-u.ac.jp
Upadhyay $ら^{1)}$ は, 脊柱や胸郭变形を有する患者を対象 として, 脊柱や胸郭の変形の種類が肺機能に与える影響を 調べており, 脊柱変形の度合いと\%肺活量とで負の相関を, 胸郭变形と機能的残気量との間で負の相関を示したとして いる. 森ら ${ }^{2)}$ は, 重症心身障害児を対象に脊柱変形と呼吸 機能の関連性を調べ, 脊柱側彎の角度と一回換気量に負の 相関を，側彎の角度と呼吸数抢よび換気効率の低さに正の 相関が認められたとしている.これらから, 脊柱や胸郭の 变形は換気量や換気効率など呼吸機能に影響を与えること がわかる.

脊柱の変形は胸腔と腹腔の容積に異変を生じさせ, コン プライアンスの変化が呼吸機能に制限を与える. また, 多 くの場合は脊柱変形に椎体の回旋が伴うため, 肋骨のアラ イメントが非対称化することで胸郭変形が生ずる. 胸郭変 形は主要な構成体である肋骨の運動性を変調させるだけで なく, 肋骨に付着する横隔膜の運動にも制限を与える.こ のように, 脊柱の変形と胸郭の変形が相まって呼吸運動に 制限が生じ，呼吸機能が制限されるのである.

この背景から, 運動機能障害を持った方の呼吸機能の維 持改善を考えるとき，いわゆる呼吸機能の検査だけでなく, 呼吸運動の制限についての評価が必要となる。具体的には, 脊柱と胸郭の変形や運動性, 横隔膜の運動性の評価が必要 である. 脊柱の変形や運動性の評価に関しては, Cobb 角や 関節可動域検査が定着している. しかし, 胸郭や横隔膜の 運動性の評価については, 運動が複雑であるという点, 計 測そのものに設備や機器を要するという点から困難である. 従って, 日常的な臨床の場面では胸郭や横隔膜の運動性の 評価は定性的な域に留まっている。このような問題意識か ら, 本論では胸郭と横隔膜の運動性を日常的に評価できる 方法論について考えたい. 


\section{3. 呼吸運動とその計測について}

\section{1 呼吸運動という現象}

呼吸運動は, 安定した脊柱を基盤として主に胸郭と横隔 膜で行われる. 吸気は呼吸筋の筋活動を伴う運動であるが, 呼気は安静呼吸の場合は拡張からの復帰による受動的な運 動である．ただし努力性の呼気では呼吸筋の筋活動を伴う 運動となる。

吸気での呼吸運動の現象を図 1 に示した. 横隔膜が収縮 して尾側に移動し肺が尾側方向に拡張される。一方で呼吸 筋の収縮により, 胸郭全体が頭側に持ち上げられるように 移動し，肺が頭側に拡張されると同時に胸郭は「バケツの 柄運動」により腹側方向と外側方向に拡張され, 肺は全て の方向に拡張されて換気を行う。胸郭は部位により優位に 肺が拡張される方向性がある. 上位胁骨では腹側・頭側方 向への拡張が，下位胁骨では側方への拡張が優位である. 背側への拡張は少ない. 肺の横・縦・前後径への合理的な 拡張を保障しているのが, バケツの柄運動である. この運 動は胁骨の円弧状の形態, 脊柱に対する斜め下方向への走 行によるものである.

乳幼児は体幹筋の未熟さから, 肋骨が春柱に対して垂直 に位置しているためバケツの柄運動が生じない。従って, 乳幼児の呼吸は胸郭の動きは少ないため横隔膜を使った腹 部有意の呼吸で換気を確保することとなる. 体幹筋の発達 により, 胁骨が斜め下に向き「バケツの柄運動」が実現さ れる.このことにより胸郭に可動性が保障され, 胸・腹式 呼吸により安定した換気が可能となる。

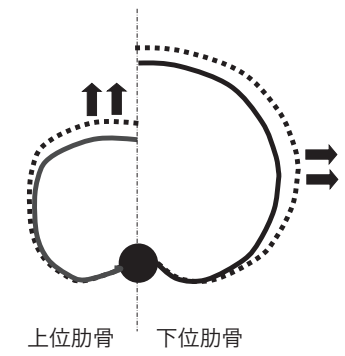

A

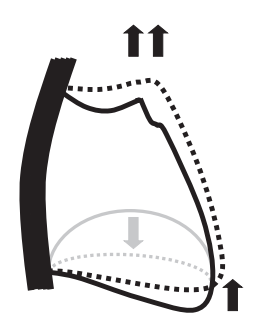

B
図 1 呼吸運動のシェマ
$\mathrm{A}$; 胸郭の水平面,
脊柱，左側：上位肋骨，右：下位胁骨
$\mathrm{B}$; 胸郭の矢状面,
脊柱
口実線：呼気時肋骨, 破線：吸気時肋骨—実線：呼気時横隔膜, 口破線：吸気時横隔膜
^: 肋骨の動きの方向と量 1 : 横隔膜の動きの方向 中村隆一ら, 基礎運動学 (第 6 版 ) 2011, p 275 より改変

\section{2 呼吸運動の計測方法}

呼吸数やスパイロメータでの検査による呼吸機能の評価 は定着しているが, 呼吸運動の評価については, 定着して いる状況ではない. 行われているのは, 呼吸運動パタンの 観察などの定性評価や, 呼吸数および胸郭や腹腔の拡張差 をメジャーで測定するという定量的評価であろう。しかし， これでは情報量が少ない. より正確な呼吸運動の量的評価 方法が求められるが, 報告されているものを紹介する.
(1) 胸郭の運動の定量的評価

胸郭の運動性の評価は放射線の撮影画像によるものがあ る. Park $ら^{3)}$ は, 脳性まひ四肢麻痺児と健常児の胸郭運動 の比較の研究で, 胸郭の正面画像から上位胸郭の横径と下 位胸郭の横径の比率を使っているが, 侵襲の大きさから評 価としての臨床応用には無理がある.

体表に貼りつけたマーカーを画像で取り込んで解析する 動作解析装置を使って測定する方法もある. Harrison ら ${ }^{4)}$ は複数の胸郭の二次元の位置データから三次元で再構成し 胸郭の偏倚を計測している。 また，ビデオ記録による方法 も提案されている. Drummond $5^{5)}$ は胸郭に照射されたレー ザー光線の投影線をビデオで撮影し，その画像をソフトウ エア上で解析して胸郭の容積の変化を算出する方法を紹介 している. スパイロメータの呼気量との関連性を調べてい るが, 胸郭の運動を胸郭の容積変化から量的に評価する手 法である.これらの方法は正確なデータが非侵襲で得られ るが, 設備装置が必要であり, 汎用は難しい.

残りの手段として, 胸郭における肋骨の動きを超音波でと らえる方法が考えられる. 報告はまだないが, 簡便で非侵襲 であるため臨床利用しやすい. 詳細を 4.にて後述したい.

(2) 横隔膜の運動の定量的評価

横隔膜の運動性の評価も放射線で撮影した画像から計測 することが可能である. 日常的な検査であり, 臨床利用で きる手法ではあるが, 侵襲の点を考えると呼吸運動評価目 的だけでは利用できない. 現実的には呼吸運動の評価手段 として使いにくい. 腹腔内圧研究の中で Hodges ら ${ }^{6)}$ は横 隔膜筋電図で測定しているが，臨床応用は困難である．残 された方法として, 超音波診断装置を利用した方法がある. 本方法は簡便で非侵襲であり, 臨床利用が可能であるので, 5.にて詳述する.

(3) 胸郭と横隔膜の運動の定量的評価

胸郭と横隔膜の運動を同時測定する方法として, 小谷ら ${ }^{7)}$ が Dynamic Breathing MRI, Tokuda ${ }^{8)}$ が Dyinamic 3D MRI という手法を報告している。これらは呼吸運動における胸 郭と肺の動きをイメージングした画像から胸郭や肺の容積 の変化や, 胸壁や横隔膜移動距離を算出する方法である. 本方法は呼吸運動を非侵襲で正確にとらえることができる 優れた評価方法であるが, 所要時間や設備, 費用上の制限 を伴う。

\section{3 超音波を使った呼吸運動の計測方法}

超音波は多くの臨床現場に配備されており, 操作・測定 も職種の制限がないという汎用性がある. 何よりも簡便で 非侵襲で身体の表面から身体の内部が測定できるというメ リットは大きい. 超音波を利用して胸郭の動きや横隔膜の 動きをとらえることは, 困難なことではない，測定方法を 4. と 5.に紹介する.

\section{4. 肋骨運動の超音波による測定方法}

胸郭の動きは肋骨の動きの集合体であるという点に着目 
し, いくつかの部位の肋骨の動きを超音波で計測する方法 を考案したので測定画面（図2）を示して説明する.

体表に近い胁骨は超音波診断装置のリニアプローブ 7.5MHz で胸郭を縦走査することで同時に二本の胁骨の動 きを捉えることができる。一走查だけでは胸郭の全貌を捉 えることができないため, 上部胸郭として 2-3肋骨を, 下 部胸郭として 7-8 肋骨を選び, それぞれ胸郭前面・側面・ 後面の一側合計 6 箇所を走查して計測した. 胸郭の各面は, 触診により 2-3 肋骨および 7-8 肋骨を同定した上で、前部は 超音波で確認した肋軟骨と肋骨の移行部, 側部は腋窩中央 からの鉛直線と各肋骨の交点, 後部は肋骨角を測定部位と した. 2-3 肋骨および 7-8 肋骨を選んだ理由は, 2-3 肋骨が 上部胸郭で超音波走查が前・側・後ろの三つの胸郭面全て で可能な最頭側部位であり, 第 7-8 肋骨が最尾側部位であ ることによる.

リニアプローブを B mode にて胸郭縦で走査すると, 呼吸 に伴ってそれぞれの部位で二本の肋骨の動きが横方向の画 像を得ることができるので, 一呼吸分を動画として保存す る. そして超音波画像解析ソフトウエア上で静止画に分割 して肋骨の移動距離を計測する。

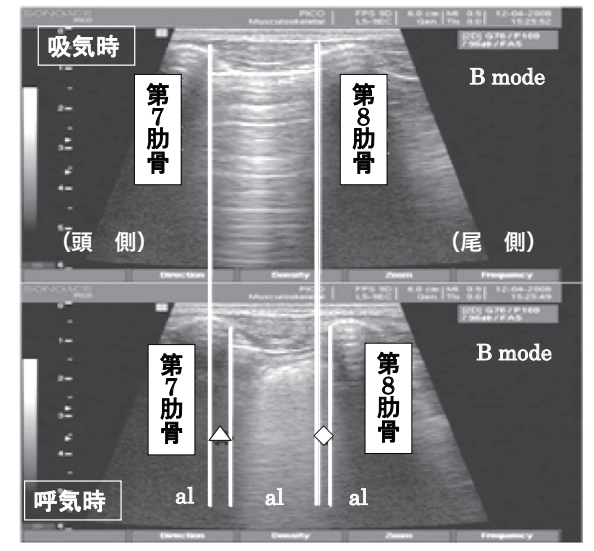

図 2 肋骨移動距離と位置の測定画面

$\triangle$ : 第 7 肋骨移動距離 $\diamond:$ : 第 8 肋骨移動距離 $\mathrm{al}$ : 測定補助線 7-8 胁骨で, B mode 動画の上段は最大吸気時、下段が最大呼気時の 静止画像を示す

それぞれの静止画像で第 7 肋骨の下縁と第 8 肋骨の上縁に al をひき, 両静止画像をソフトウエア上で統合し $\triangle \diamond を$ 測定した

\section{5. 横隔膜運動の超音波による測定方法}

超音波での横隔膜の測定では, 報告されている二つの方 法を以下に解説する。

\section{1 門脈左枝から横隔膜の動きを測定する方法（肋骨弓下 縦走査)}

横隔膜右側直下に位置する肝臟は横隔膜の動きと同時に 頭尾側方向に動くため, 肝臓の動きから横隔膜の動きを推 定する間接的な方法である. 測定原理を図 3 に示して解説 する.
超音波診断装置を使って B mode にて右側の胁骨弓下縦走 查をコンベックスプローブ $3.5 \mathrm{MHz}$ で行うことで, 肝臟に て水平方向に走行している門脈左枝が楕円形様に確認でき る. 肝臓は横隔膜の直下にあり, 呼吸によって頭尾方向に 横隔膜と同様に動く. 門脈左枝も肝臓と同様に呼吸に伴い 頭尾方向に動く. 超音波診断装置 B mode にて呼吸で移動す る門脈左枝の横断面をとらえることができる. 門脈左枝の 横断面は生体では頭尾側方向に移動するが, 画像上ではプ ローブの位置関係から左右方向の動きとして表される.こ の動きを測定キャリパーで測定して, 右側の横隔膜移動距 離とみなす。

Toledo $\check{~}^{9)}$ は, この方法で 51 名の患者の横隔膜の移動距 離の測定を行なった。 その結果, 横隔膜移動距離は放射線 の透視画像で測定した值と正の相関 $(\mathrm{r}=0.65, \mathrm{p}<0.01)$ を認め たと報告している。 また, Yamaguti $ら^{10)}$ は同様の方法で横 隔膜の移動距離を 7 名の健常者で測定し, 右側が床に接し た側臥位の方が横隔膜の移動距離が大きいことを示している。

この方法は技術的に平易であり, 実際の横隔膜の動きと の相関も高いことから臨床的に利用できる方法である. し かし, 測定が右側の横隔膜に限られる, 疾病により肝臟や 消化器の癒着などがある場合は横隔膜と肝臓の動きの連動 性が保障されないため, 測定に適さないという限界も有し ている.

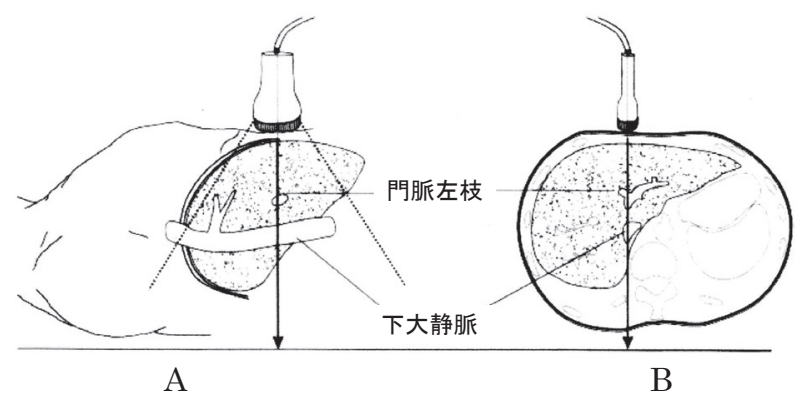

図 3 門脈左枝から横隔膜の動きを測定する方法

$$
\mathrm{A} \text {; 矢状面図 } \mathrm{B} \text {; 水平面図 }
$$

胁骨弓下の正中線より右側の部位にプローブを縦にあて, B mode にて楕円形に結像する門脈左枝の横断面をとらえる. この横断面は 生体では呼吸に合わせて頭尾方向に移動するが, 測定画面上はプ ローブとの位置関係から左右方向に移動する．横断面の移動距離を 計測キャリパーで計測する

\section{2 横隔膜を直接とらえて測定する方法 (肋骨弓下斜走査)}

横隔膜を捉えて動きを測定する直接的な方法である。そ の測定原理を図 4 で示し，併せて図 5 に測定画面を示して 解説する.

超音波診断装置を使って B mode にて右側の胁骨下斜走査 をコンベックスプローブ $3.5 \mathrm{MHz}$ で行うことで, 胸壁側の ドーム状の彎曲部である横隔膜の後外側部を尾側から捉え ることができる. B mode 画面上で横隔膜は下方凸に彎曲し た高輝度の曲線として容易に同定可能である. 直ちに, 描 出された横隔膜の曲線の最凸部分が画面上のプローブから 
のビームのライン（画面上は垂直の点線で表示される）と 合うようにプローブをコントロールし，B mode 画像を決定 する. この操作により横隔膜に対してプローブが垂直に位 置する.この状態を保って M mode に切り替えれば横隔膜 の移動距離の測定が可能となる.

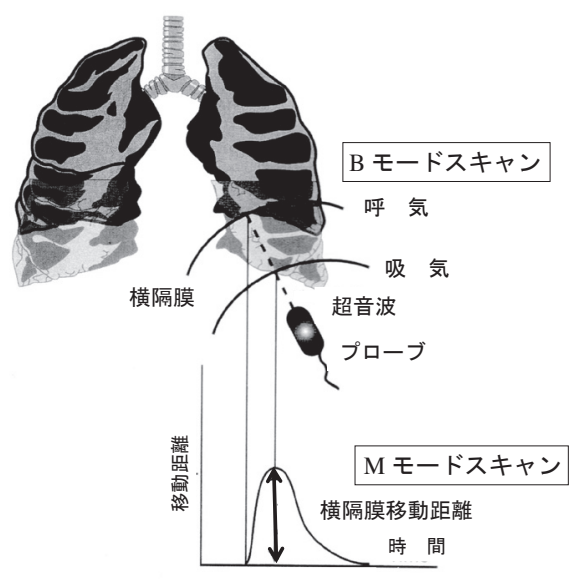

図 4 横隔膜を直接とらえて測定する方法

文献 ${ }^{11)}$ Epelman,2005 より改変. 肋骨弓下で胁骨縁に沿うようにコ ンベックスプローブ $3.5 \mathrm{MHz}$ を斜めに走査し, 胸壁に近い横隔膜の 後外側部分の動きを尾側から捉える

M mode 画面上にはすでに, 高輝度の横隔膜の動きがサイ ンカーブ様に描出されている. M modeでは横軸に時間, 縦 軸に横隔膜の偏倚量が示される. 画面の移動速度は速すぎ ると一呼吸分を画面内に捉えることができないので, 移動 速度を一番遅く設定し，一呼吸が画面内に入るようにして M mode の測定画面を確定する. 測定マーカーを使って超音 波診断装置の長さ測定機能を使って測定する. 描出された サインカーブは, 下の頂点は横隔膜が弛緩した位置を, 上 の頂点は横隔膜が収縮した位置を示す．それぞれの頂点の 体表からの距離を測定し, その差を横隔膜移動距離として 算出する.

この方法は簡便であり, 左右の横隔膜が測定できるとい うメリットがあるが, 脊柱・胸郭変形などで横隔膜が高位 にある場合には超音波で捉えきれない場合がある。また， 左の横隔膜は右に比べて描出できない場合もあるという問 題を持っている ${ }^{11)}$. 更に, プローブの位置や角度や接触圧 の強さは, 横隔膜の画像を得ることができるために個人差 があることから, 常に一定の部位の胁骨弓下から横隔膜の 位置を捉えることが難しい. 従って, 横隔膜の移動距離を 正確に捉えることはできるが、椎体に対する位置変化を正 確に示すことは難しい.

Epelman $ら^{11)}$ は 278 名の小児に, Kantarci ら ${ }^{12)}$ は仰臥位 にて 164 名の健常成人を対象に, Boussuges $5^{13)}$ は立位にて 210 名の健常成人に対して, 本手法を利用して左右の横隔膜 の移動距離を測定し, 標準的な横隔膜移動距離を示してい る. また, Cohen $5^{14)}$ は脳卒中後遺症片麻痺の横隔膜移動
距離の測定に, Ayoub ${ }^{15)}$ は胆囊切除後の横隔膜の動きに 評価に, Lloyd $5^{16)}$ は横隔膜麻痺の診断に本手法を利用し た報告を行っている．筆者らは，種々の姿勢での横隔膜の 動きを本手法で計測したが，結果を6.で示す.

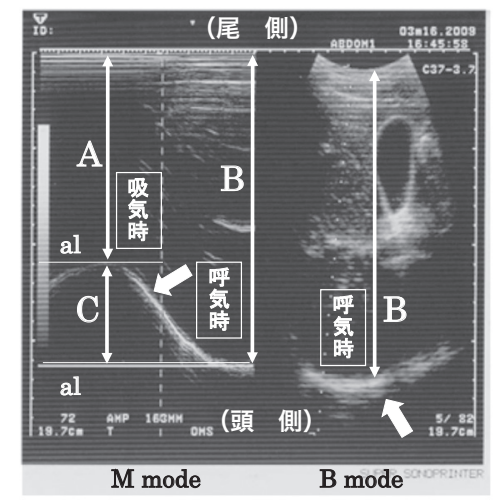

図 5 横隔膜移動距離と位置の測定画面

$\mathrm{A}$ ：横隔膜収縮時における体表・プローブからの距離, B：横隔膜 弛緩時における体表・プローブからの距離, $\mathrm{C}$ : 横隔膜移動距離 $(\mathrm{C}$ $=\mathrm{B}-\mathrm{A}), \mathrm{al}$ : 測定補助線

左：B mode で横隔膜（凹）を確認し, 右：M mode で横隔膜の動 きを示すサインカーブ (®) の上・下頂点に $\mathrm{al}$ をひき, A と B を 測定し C を算出した

\section{6. 超音波による肋骨と横隔膜の運動計測紹介 6.1 対象}

健常成人男性 10 人 (平均 $21.0 \pm 0.30$ 歳, 平均身長 170.0 $\pm 5.41 \mathrm{~cm}$, 平均体重 $62.1 \pm 5.38 \mathrm{Kg}$ ) を対象とした.

\section{2 方法}

呼吸援助の理学療法介入を想定し, いくつかの異なる姿 勢で, 安静呼吸および努力性呼吸での胁骨と横隔膜の運動 測定を行なうこととする. 今回は実験的に横隔膜と肋骨の 動きを二台の超音波診断装置にて同時に測定した. 安静呼 吸とは通常の呼吸状態のことであり, 努力性呼吸とは深呼 吸のことを指す。深呼吸は連続して行わないように配慮し て計測した。 なお, 測定に先立ち, 採用した測定方法の検 者内信頼性の検討をおこない, 該当する検者が測定するこ とで精度を保障した。

(1) 肋骨運動の測定方法

4 で示した方法を用い，測定姿勢は仰臥位、座位、左下側 臥位、右下側臥位、伏臥位の姿勢とし, 安静呼吸および努 力性呼吸にて, 第 2-3 肋骨および第 7-8 肋骨の前面・側面・ 後面について計測した. 今回は右肋骨のみの計測としたため, 仰臥位の後面, 右下側臥位の側面, 伏臥位の前面は測定か ら除外した. 数回の予備呼吸で安定した呼吸状態を超音波画 像上で確認した後に一呼吸分について計測した。超音波診 断装置はSONOACE PICO (MEDISON 製) を用い, リニア プローブ $7.5 \mathrm{~Hz}$ にて胸郭表面から走査して B mode 動画を得, 解析ソフトウエア Ultrasound DiVer（ユー・エス・ディー製） 
で長さ計測機能により肋骨移動距離を測定した（図 2).そ れぞれの部位での 1 回の計測值を基礎データとした.

(2) 横隔膜運動の測定方法

5.2 で示した方法を用い, 測定姿勢は仰臥位、座位、左 下側臥位、右下側卧位の姿勢とし, 努力性呼吸および安静 呼吸にて横隔膜の動きを測定した。伏臥位は測定が困難な ため, 測定除外とした。超音波診断装置は Duro-US（東芝 社製）を用い，コンベックスプローブ $3.5 \mathrm{~Hz}$ にて胁骨弓下 から走查して B mode にて横隔膜を確認し, M modeの画面 上にて左右の横隔膜の動きを測定した（図 5). 肋骨と同時 測定したため, 一つの姿勢で 6 回のデータが得られるため, 最大・最小值を除外した 4 つのデータの平均值を個々の基 礎データとした。

(3) 統計処理

検者内信頼性の検討は級内相関 $\operatorname{ICC}(1,1)$ を用いた．基 礎データ 10 名分の中央值の比較について, 二群比較に は Wilcoxon の符号順位検定を, 姿勢比較は Friedman 検 定とScheffe の多重比較を用いた。 基礎データ間の相関は Spearman の順位相関係数を用いた. 全て, 有意水準 $5 \%$ に て検討した。

\section{3 測定の信頼性に関する結果}

胁骨の測定では, 第 2 肋骨と第 3 肋骨の移動距離で検者 内信頼性を確認した. $\operatorname{ICC}(1,1)$ は第 2 肋骨で 0.94 , 第 3 肋 骨で 0.78 であった。横隔膜の測定では横隔膜の弛緩時と収 縮時の位置で確認した. ICC $(1,1)$ は弛緩時で 0.941 , 収縮時 0.908 であった. 総じて高い検者内信頼性が確認された. 本 測定方法の信頼性の高さが示された.

\section{4 肋骨運動の測定データから}

肋骨運動の全計測結果を表 1 に示す.

肋骨の移動距離は全ての姿勢と胁骨の位置と部位で, 安 静呼吸に比べて努力性呼吸で有意に大きかった（図 6)。こ の結果は教科書的な知見と一致し, 測定の正確さを示すが 17)，以下に標準的な日常姿勢である座位で見てみる．胁骨 の移動距離は, 胸郭前面と後面において安静呼吸では 2-3 肋骨 2 2.5mm, 7-8 肋骨 2.5 3mm であるが, 努力性呼吸で は順に 5 7mm, 7 10 $\mathrm{mm}$ の動きとなる. 一方, 胸郭後面の 安静呼吸は 2-3 肋骨, 7-8 肋骨とも $1.5 \mathrm{~mm}$ 前後だが, 努力性 呼吸になると 2-3 肋骨 4 5 $5 \mathrm{~mm}, 7-8$ 肋骨 $7 \mathrm{~mm}$ の動きとな
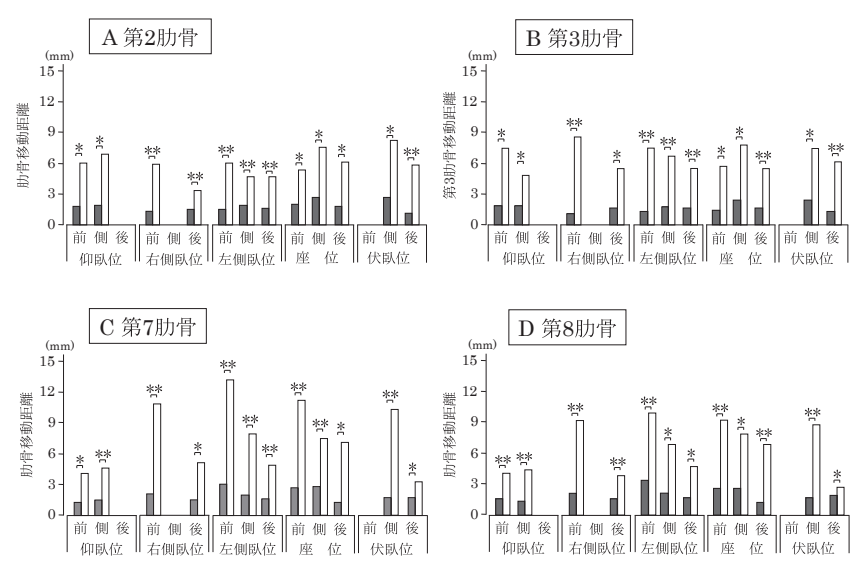

図 6 肋骨移動距離の中央值における安静・努力性呼吸比較

前：胸郭前面 側：胸郭側面 後：胸郭後面,

A : 第 2 肋骨 B : 第 3 肋骨 C : 第 7 肋骨 D : 第 8 胁骨

口安静呼吸 $\square$ 努力性呼吸 $* * \mathrm{p}<0.01 \quad * \mathrm{p}<0.05$

表 1 安静・努力性乎吸における姿勢別の右胁骨移動距離の值

\begin{tabular}{|c|c|c|c|c|c|c|c|c|c|c|c|c|c|c|c|c|c|}
\hline & 呼吸 & 胸郭 & 仰 監 & 位 & $(\mathrm{n}=10)$ & 右下俱 & 臥位 & $(\mathrm{n}=10)$ & 左下俱 & 臥位 ( & $(n=10)$ & 座 & 位 & $(\mathrm{n}=10)$ & 伏 監 & 位 & $(\mathrm{n}=10)$ \\
\hline & & 部位 & Med & Min & $\operatorname{Max}$ & Med & Min & $\operatorname{Max}$ & Med & Min & Max & Med & Min & Max & Med & Min & Max \\
\hline \multirow{6}{*}{$\begin{array}{c}\text { 第 } \\
2 \\
\text { 胡 } \\
\text { 骨 }\end{array}$} & & 前 & 1.80 & 0.80 & 3.30 & 1.35 & 0.80 & 2.40 & 1.50 & 0.60 & 3.20 & 2.05 & 0.70 & 4.80 & & & \\
\hline & 安 静 & 側 & 1.95 & 0.90 & 620 & & & & 1.90 & 0.90 & 220 & 2.60 & 1.80 & 8.90 & 2.70 & 1.50 & 3.90 \\
\hline & & 後 & & & & 1.50 & 0.80 & 2.10 & 1.65 & 0.70 & 2.80 & 1.90 & 0.80 & 3.70 & 1.15 & 0.70 & 2.80 \\
\hline & & 前 & 6.10 & 1.80 & 13.90 & 6.00 & 1.90 & 21.20 & 6.05 & 2.00 & 18.80 & 5.40 & 1.80 & 15.10 & & & \\
\hline & 努力性 & 側 & 6.90 & 3.00 & 23.50 & & & & 470 & 3.00 & 18.90 & 7.55 & 3.20 & 2420 & 825 & 2.10 & 32.10 \\
\hline & & 後 & & & & 3.40 & 1.40 & 10.60 & 4.70 & 2.00 & 20.20 & 4.05 & 0.60 & 15.80 & 5.85 & 3.00 & 11.90 \\
\hline \multirow{6}{*}{$\begin{array}{c}\text { 第 } \\
3 \\
\text { 胡 } \\
\text { 骨 }\end{array}$} & & 前 & 1.85 & 1.00 & 3.30 & 1.05 & 0.60 & 2.10 & 1.35 & 0.80 & 1.40 & 1.40 & 0.40 & 5.30 & & & \\
\hline & 安 静 & 側 & 1.90 & 0.70 & 3.50 & & & & 180 & 0.50 & 280 & 2.45 & 1.60 & 5.60 & 2.40 & 1.70 & 4.90 \\
\hline & & 後 & & & & 1.35 & 0.80 & 3.10 & 1.60 & 0.40 & 3.70 & 1.60 & 0.40 & 3.40 & 1.35 & 0.90 & 2.90 \\
\hline & & 前 & 7.45 & 2.20 & 21.70 & 8.60 & 2.60 & 23.40 & 7.50 & 1.00 & 20.80 & 5.75 & 0.60 & 16.80 & & & \\
\hline & 努力性 & 側 & 490 & 3.10 & 2220 & & & & 675 & 1.80 & 24.00 & 785 & 3.00 & 19.80 & 750 & 2.30 & 31.90 \\
\hline & & 後 & & & & 3.05 & 2.90 & 10.20 & 5.55 & 2.10 & 21.30 & 5.55 & 1.60 & 12.50 & 6.20 & 2.90 & 10.10 \\
\hline \multirow{6}{*}{$\begin{array}{c}\text { 第 } \\
7 \\
\text { 䏦 } \\
\text { 骨 }\end{array}$} & & 前 & 1.30 & 0.20 & 3.20 & 2.10 & 1.10 & 4.20 & 3.05 & 0.70 & 4.70 & 2.70 & 1.60 & 5.50 & & & \\
\hline & 安 静 & 側 & 175 & 0.70 & 220 & & & & 2.05 & 1.00 & 380 & 2.85 & 1.00 & 6.40 & 1.80 & 1.30 & 730 \\
\hline & & 後 & & & & 1.50 & 0.70 & 2.40 & 1.65 & 0.80 & 2.30 & 1.30 & 0.30 & 2.20 & $1.70^{\circ}$ & 0.60 & 3.50 \\
\hline & & 前 & 4.15 & 1.10 & 7.20 & 10.85 & 2.80 & 33.60 & 13.20 & 1.80 & 23.50 & 11.30 & 2.30 & 18.40 & & & \\
\hline & 努力性 & 側 & 4.65 & 2.20 & 13.50 & & & & 795 & 4.60 & 18.40 & 7.50 & 2.10 & 35.30 & 10.30 & 5.00 & 19.30 \\
\hline & & 後 & & & & 5.20 & 0.60 & 9.00 & 4.90 & 2.10 & 8.00 & 7.15 & 2.90 & 15.30 & 3.25 & 2.10 & 6.30 \\
\hline \multirow{6}{*}{$\begin{array}{c}\text { 第 } \\
8 \\
\text { 胡 } \\
\text { 骨 }\end{array}$} & & 前 & 1.60 & 1.00 & 2.90 & 2.10 & 0.90 & 2.70 & 3.35 & 0.70 & 8.20 & 2.65 & 1.60 & 4.50 & & & \\
\hline & 安 静 & 側 & 140 & 0.90 & 220 & & & & 2.15 & 0.40 & 4.60 & 2.60 & 1.00 & 5.50 & 1.65 & 0.64 & 4.50 \\
\hline & & 後 & & & & 1.55 & 0.50 & 2.00 & 1.05 & 0.70 & 3.10 & 1.25 & 0.50 & 2.40 & 1.90 & 0.90 & 3.60 \\
\hline & & 前 & 4.05 & 2.50 & 6.80 & 9.95 & 4.00 & 31.90 & 9.95 & 4.60 & 18.90 & 9.30 & 2.40 & 11.90 & & & \\
\hline & 努力性 & 側 & 440 & 3.00 & 5.90 & & & & 685 & 2.40 & 19.70 & 795 & 0.70 & 30.70 & 8.80 & 3.40 & 20.50 \\
\hline & & 後 & & & & 3.80 & 0.30 & 8.40 & 4.75 & 19.70 & 9.80 & 6.85 & 2.90 & 15.70 & 2.70 & 2.00 & 10.30 \\
\hline
\end{tabular}

Med : 中央值, Min : 最小值, Max : 最大值 安静 : 安静呼吸 努力性 : 努力性呼吸 前: 胸郭前部

側：胸郭側部 後：胸郭後部 右側臥：右下側臥位 左側臥：左下側臥位 
る.この結果から, 安静呼吸では何れの胁骨も同程度の動 きだが, 努力性呼吸になると前・側面で 2 3 倍, 後面では 3 6 倍に増加することがわかる. 努力性呼吸では安静呼吸で 動きの少ない胸郭後面の肋骨の動きも多く動員されている. この事実は呼吸援助の理学療法にとって, 脊柱抢よび胸郭 後面の可動性の重要性を示唆している.

次に隣り合う肋骨を詳しく見てみる. 安静呼吸では 2-3 胁骨, 7-8 肋骨ともそれぞれ同様の動きである. しかし努力 性呼吸では 2 肋骨に比べて 3 胁骨が，8胁骨に比べて 7 肋骨 が多く動く傾向を有している. この傾向は下位胁骨の方が 強く現れているようである（図 7).

この事実は胁骨の部位によって呼吸援助の方法に変化を 与える必要性を示唆している.
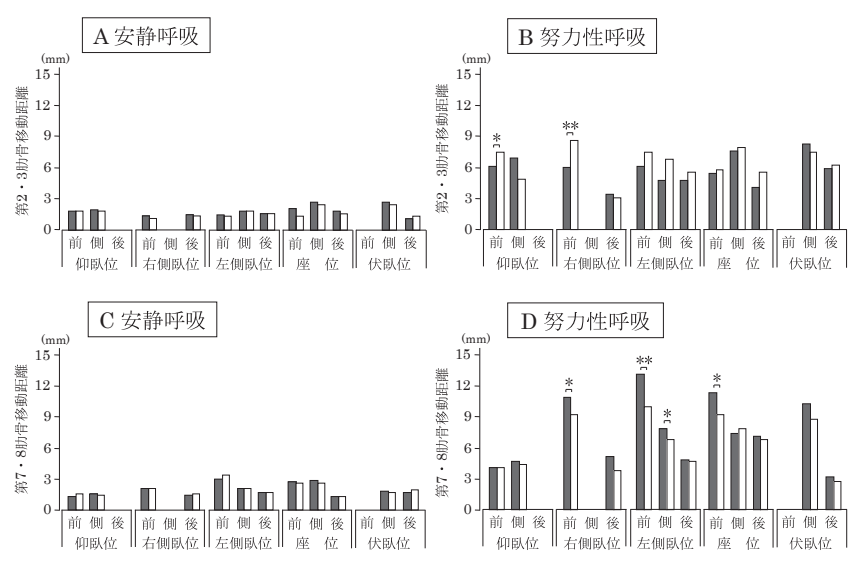

図 7 肋骨移動距離の中央值における肋骨比較

前：胸郭前面 側：胸郭側面 後：胸郭後面

A : 安静呼吸, 胁骨移動距離の第 $2 \cdot 3$ 肋骨比較

B : 努力性呼吸, 胁骨移動距離の第 $2 \cdot 3$ 肋骨比較

口第 2 肋骨移動距離 $\square$ 第 3 肋骨移動距離

** $\mathrm{p}<0.01 * \mathrm{p}<0.05$

C : 安静呼吸, 胁骨移動距離の第 $7 \cdot 8$ 肋骨比較

$\mathrm{D}$ : 努力呼吸, 胁骨移動距離の第 $7 \cdot 8$ 肋骨比較

口第 7 肋骨移動距離 $\square$ 第 8 肋骨移動距離 $\quad * * \mathrm{p}<0.01 \quad * \mathrm{p}<0.05$
姿勢の比較で見てみると, 2-3 肋骨では呼吸方法に関らず 姿勢による差が無かったが，7-8胁骨ではどちらの呼吸でも 姿勢差を認め, その傾向は努力性呼吸に強い，その中でも側 臥位では胸郭前面が，座位・伏臥位では胸郭側面で移動距 離が大きい傾向があった（図 8)。この事実は，呼吸援助の 姿勢選択に側卧位や座位を選択する根拠になる可能性がある.

\section{5 横隔膜運動の測定データから}

横隔膜運動の計測結果を表 2 に示す.

努力性呼吸での仰臥位での横隔膜移動距離は Kantarci ら 12)の結果とほぼ一致しており, 測定結果の妥当性を示して いる，横隔膜収縮位置は，姿勢に関わらず努力性呼吸より 安静呼吸で長いが, 横隔膜驰緩位置は姿勢・呼吸様式に関 わらずほとんど差がなかった，横隔膜移動距離は，姿勢に 関わらず安静より努力性呼吸で長かった（図 9）。この結果 は解剖学扔よび生理学的な知見と一致している ${ }^{17-199}$.

横隔膜収縮・弛緩時の位置は呼吸様式に関わらず右下側 臥位では左より右横隔膜で, 左下側臥位では右より左横隔 膜で長かったが, 仰臥位と座位では横隔膜の位置に左右差 がなかった．横隔膜の移動距離は呼吸様式に関わらず右下 側臥位で左より右横隔膜で大きかったが，他の姿勢では左 右差がなかった（図 10)。 また, 姿勢比較では, 右横隔膜 では姿勢様式に関わらず左下より右下側臥位で横隔膜の移 動距離が大きかった, 左横隔膜では姿勢差が無かった（図 11).この結果は右下側臥位が呼吸援助に有利な姿勢である 可能性を示唆している.

\section{6 肋骨運動と横隔膜運動の相関関係から}

胁骨運動と同期して測定した横隔膜の運動において, 以 下のような相関関係がみられた。

左下側臥位では, 努力性呼吸において, 右横隔膜移動距 離と右胸郭後面 2-3 肋骨に正の相関 $(r=0.76-r=0.69, \mathrm{p}<0.05)$

表 2 安静・努力性乎吸における姿勢別の横隔膜移動距離・位置の值

\begin{tabular}{|c|c|c|c|c|c|c|c|c|c|c|c|c|}
\hline \multirow{2}{*}{$\begin{array}{l}\text { 測定 } \\
\text { 項目 }\end{array}$} & \multirow{2}{*}{$\begin{array}{l}\text { 呼吸 } \\
\text { 様式 }\end{array}$} & \multirow{2}{*}{$\begin{array}{c}\text { 横隔 } \\
\text { 膜 }\end{array}$} & \multirow{2}{*}{$\begin{array}{c}\text { 仰 } \\
\text { Med } \\
\end{array}$} & \multirow{2}{*}{$\frac{\text { 位 }}{\operatorname{Min}}$} & \multirow{2}{*}{$\frac{(\mathrm{n}=10)}{\operatorname{Max}}$} & \multicolumn{2}{|c|}{ 右下側臥位 } & \multirow{2}{*}{$\frac{(\mathrm{n}=10)}{\operatorname{Max}}$} & \multicolumn{2}{|c|}{ 左下側臥位 } & \multirow{2}{*}{$\begin{array}{r}(\mathrm{n}=10) \\
\operatorname{Max}\end{array}$} & \multirow{2}{*}{$\frac{\text { 座 }}{\mathrm{Med}}$} \\
\hline & & & & & & Med & Min & & Med & Min & & \\
\hline \multirow{4}{*}{$\begin{array}{l}\text { 弛 } \\
\text { 緩 } \\
\text { 位 } \\
\text { 置 }\end{array}$} & \multirow{2}{*}{ 安 } & 右 & 151.5 & 136.5 & 167.8 & 160.6 & 147.5 & 173.0 & 125.5 & 112.7 & 143.5 & 143.5 \\
\hline & & 左 & 156.0 & 126.0 & 168.0 & 127.0 & 107.0 & 141.0 & 156.5 & 134.0 & 183.0 & 136.5 \\
\hline & \multirow{2}{*}{ 努力性 } & 右 & 149.5 & 132.5 & 160.8 & 159.7 & 151.3 & 172.5 & 130.2 & 113.8 & 149.3 & 146.9 \\
\hline & & 左 & 160.0 & 134.0 & 174.0 & 118.5 & 112.0 & 135.0 & 163.0 & 150.0 & 175.0 & 137.0 \\
\hline \multirow{4}{*}{$\begin{array}{l}\text { 収 } \\
\text { 縮 } \\
\text { 位 } \\
\text { 置 }\end{array}$} & \multirow{2}{*}{ 安 } & 右 & 128.3 & 108.4 & 159.0 & 144.2 & 112.3 & 156.8 & 115.2 & 104.8 & 133.3 & 122.6 \\
\hline & & 左 & 135.0 & 97.6 & 154.0 & 115.0 & 99.0 & 137.0 & 143.5 & 132.0 & 166.0 & 125.5 \\
\hline & \multirow{2}{*}{ 努力性 } & 右 & 94.1 & 77.6 & 125.5 & 98.9 & 84.8 & 152.0 & 97.8 & 81.2 & 120.0 & 101.9 \\
\hline & & 左 & 107.0 & 80.3 & 144.0 & 95.9 & 84.3 & 116.0 & 119.5 & 91.3 & 156.0 & 104.0 \\
\hline \multirow{4}{*}{$\begin{array}{l}\text { 移 } \\
\text { 動 } \\
\text { 距 } \\
\text { 離 }\end{array}$} & \multirow{2}{*}{ 安＼cjkstart静 } & 右 & 15.8 & 6.3 & 34.8 & 16.6 & 7.8 & 39.5 & 9.5 & 3.3 & 19.9 & 12.6 \\
\hline & & 左 & 14.0 & 6.0 & 29.0 & 7.0 & 2.0 & 17.0 & 10.5 & 2.0 & 23.0 & 11.0 \\
\hline & \multirow{2}{*}{ 努力性 } & 右 & 55.2 & 25.8 & 70.2 & 60.5 & 17.8 & 67.9 & 30.8 & 11.2 & 64.2 & 42.1 \\
\hline & & 左 & 50.0 & 30.0 & 79.5 & 20.6 & 14.0 & 36.0 & 35.0 & 13.0 & 69.7 & 33.4 \\
\hline
\end{tabular}

Med : 中央值, Min : 最小值, Max : 最大值 安静 : 安静呼吸 努力性 : 努力性呼吸 前: 胸郭前部 側：胸郭側部 後：胸郭後部 右側臥：右下側臥位 左側臥：左下側臥位 
がみられ, 胸郭側面 7-8 肋骨に正の相関 $(r=0.82-r=0.75$, $\mathrm{p}<0.05)$ がみられた. また, 仰臥位では, 横隔膜移動距離と 努力性呼吸で胸郭前面 3 肋骨と正の相関 $(r=0.67, p<0.05)$ が, 右下側臥位では, 努力性呼吸で右横隔膜移動距離と胸郭後 面 8 肋骨と正の相関 $(r=0.73, \mathrm{p}<0.05)$ が認められた. 側臥位 と横隔膜の動きの相関が多く示されたことは, 呼吸援助に とって側臥位を選択する根拠になる可能性がある.
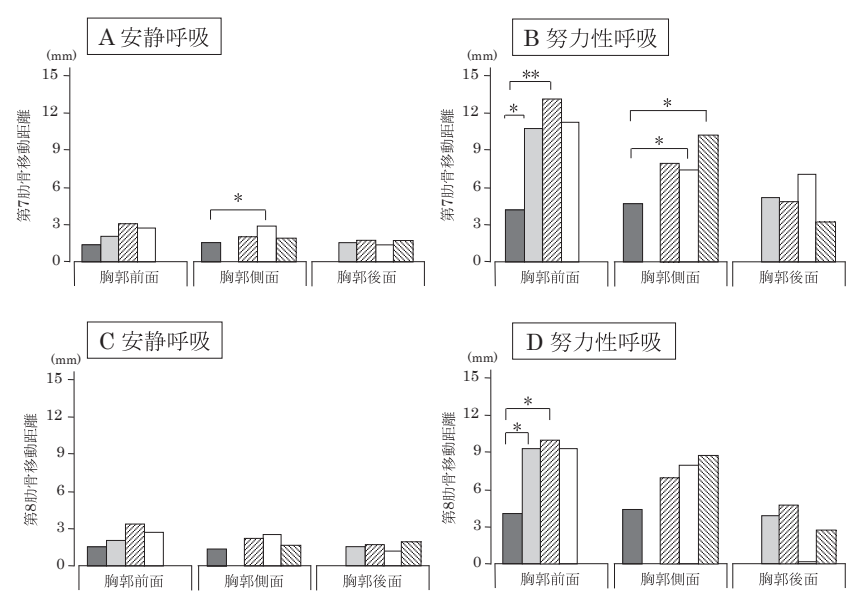

図 $8 \quad 7 \cdot 8$ 肋骨移動距離の中央值における姿勢比較

A : 安静呼吸, 第 2 肋骨移動距離での姿勢比較

B : 努力性呼吸, 第 2 肋骨移動距離での姿勢比較

C : 安静呼吸, 第 3 肋骨移動距離での姿勢比較

D : 努力性呼吸, 第 3 肋骨移動距離での姿勢比較

口仰臥位 右下側臥位 四左下側臥位 $\square$ 座位 伏臥位 ** $\mathrm{p}<0.01 \quad * \mathrm{p}<0.05$
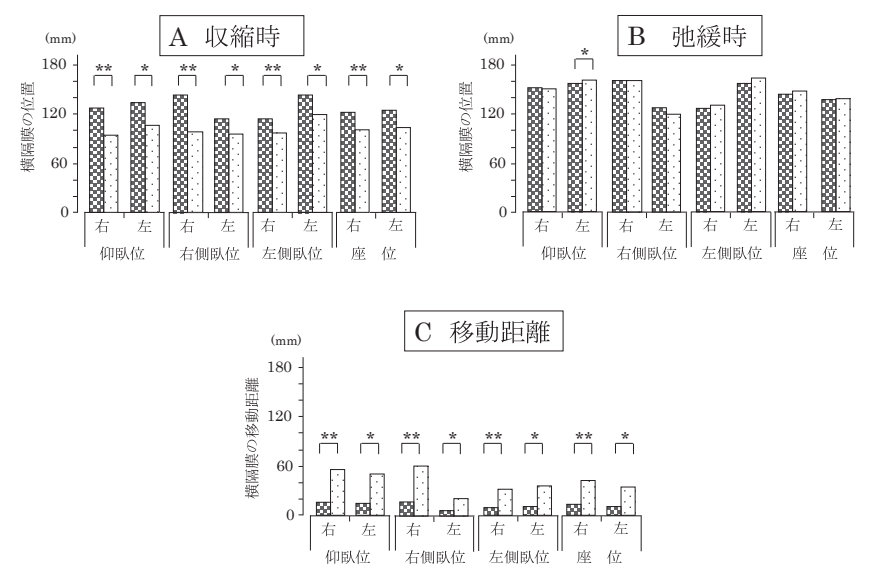

図 9 横隔の位置・移動距離の中央值における安静・努力性呼吸の 比較

A : 横隔膜の収縮時位置の中央值における安静・努力性呼吸の比較 B : 横隔膜の弛緩時位置の中央值における安静 - 努力性呼吸の比較 C : 横隔膜の移動距離の中央值における安静・努力性呼吸の比較 右: 右横隔膜 左: 左横隔膜图安静呼吸努力性呼吸 ** $\mathrm{p}<0.01 \quad * \mathrm{p}<0.05$

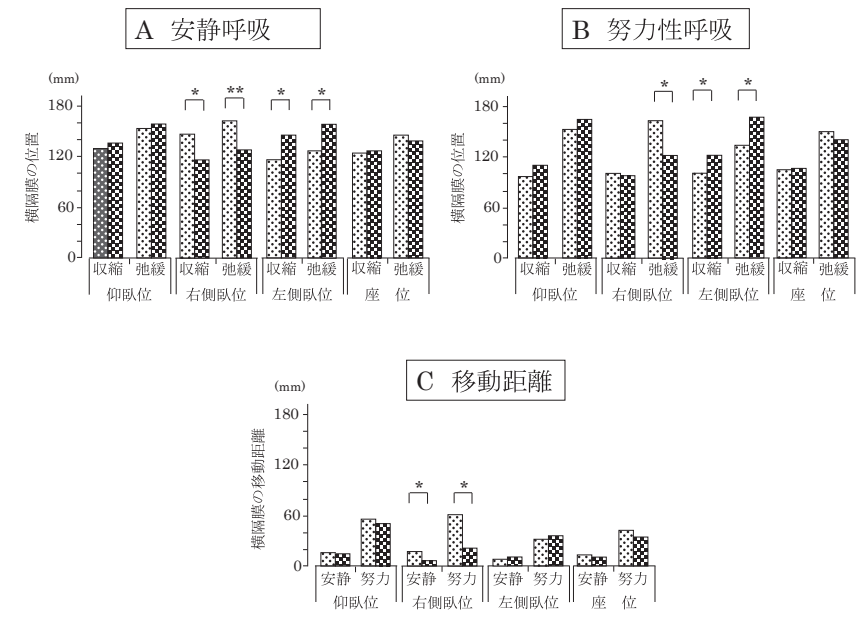

図 10 横隔膜の位置・移動距離の中央值における左右の比較

A : 安静呼吸, 横隔膜位置の中央值における左右での比較

B : 努力性呼吸, 横隔膜位置の中央值における左右での比較

C : 横隔膜の移動距離の中央值における左右での比較

収縮：収縮時の横隔膜位置 弛緩: 弛緩時の横隔膜位置 圈右横隔膜 图左横隔膜 $\quad * * \mathrm{p}<0.01 \quad * \mathrm{p}<0.05$
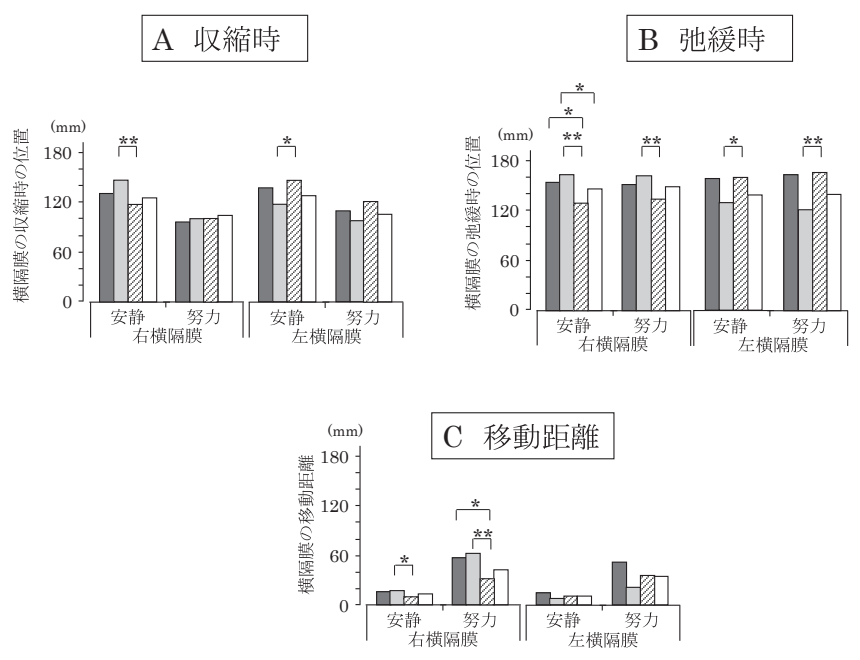

図 11 横隔の位置・移動距離の中央值における姿勢による比較

$\mathrm{A}$ ：横隔膜の収縮時位置の中央值における姿勢による比較

B : 横隔膜の弛緩時位置の中央值における姿勢による比較

C : 横隔膜の移動距離の中央值における姿勢による比較

口仰臥位 口右下側臥位 四左下側臥位 $\square$ 座位 $* * \mathrm{p}<0.01$ $* \mathrm{p}<0.05$

\section{7. 超音波計測の問題点と展望, 臨床応用へ}

体表から身体内部の運動をとらえやすいのが超音波の利 点であるが限界性も有する。プローブを固定する必要があ るために測定が静的運動に制限されるという制限があり, 動 的な運動での計測が困難である. また, 胁骨部分の運動と 胸郭全体の動きの関連性も十分明らかではない.これらの 解決には異なる方法論も動員して研究を重ねる必要がある.

重症心身障害の方など, 脊柱や胸郭に高度の変形がある 
場合は肋骨の走行方向や横隔膜位置の偏倚により超音波で 走查不能となる可能性も考えられる. また, 左横隔膜の測 定が技術的に困難であることは手法的・技術的な限界であ る. この点は今後の計測の積み重ねの中で可能性と限界を 明らかにしていく必要がある.

呼吸運動を援助するために呼吸運動の評価は大切である が，超音波で簡便な方法でも再現性が良い測定ができた。 測定結果は吸気時の肋骨の動きは肋骨の位置や部位によっ て動き方に差があることを示し，より効率的な呼吸援助方 法に示唆を与えている. また, 姿勢によって横隔膜の動き が変わることも示され，呼吸援助の姿勢設定に影響を与え るであろう. 呼吸機能の維持と改善の重要性に鑑み, 呼吸 運動の評価がより正確に, より簡単に行うことができるよ う, 今後も評価方法の工夫と改良が求められるところである. 一方, 呼吸運動の評価のためには基準となるデータが必要 である. 本データは大学生 10 名の範囲で基準としては弱い. より多くの対象者や年齢層で姿勢別の肋骨や横隔膜の動き を測定し, 評価の判断基準を示す必要がある.

簡便な測定・評価でなければ臨床には応用されにくい. 簡便で正確な評価は, 負担が少なく, かつ最大限の効果が もたらされる保障でもある. かかる評価方法が工夫・開発 されることを願って止まない.

\section{参考文献}

1) Upadhyay, S.S., Mullaji, A.B., Luk, K.D. and Leong, J.C. : Relation of spinal and thoracic cage deformities and their flexibilities with altered pulmonary functions in adolescent idiopathic scoliosis, Spine, 20(22), 2415-2420, (1995).

2) 森直樹, 黒澤一, 松本香好美, 伊藤愛子, 伊藤友一, 藤 原健一, 上月正博: 重症心身障害児 (者) の脊柱変形と 呼吸機能の相関，脳と発達，38(1)，10-14，(2006).

3) Park, E.S., Park, J.H., Rha, D.W., Park, C.I. and Park C.W. : Comparison of the ratio of upper to lower chest wall in children of spastic quadriplegic cerebral palsy and normally developed children, Yonsei Medical Journal, 47(2), 237242, (2006).

4) Harrison, D.E., Janik, T.J., Cailliet, R., Harrison, D.D., Normand, M.C., Perron, D.L. and Ferrantelli, J.R. : Validation of a computer analysis to determine 3-D rotations and translations of the rib cage in upright posture from three 2-D digital images, Eur Spine J, 16(2), 213-218, (2007).

5) Drummond, G.B. and Duffy, N.D. : A video-based optical system for rapid measurements of chest wall movement, Physiol Meas, 22(3), 489-503, (2001)

6) Hodges, P.W. and Gandevia, S.C. : Changes in intraabdominal pressure during postural and respiratory activation of the human diaphragm, J Appl Physiol, 89(3), 967-976, (2000)

7) 小谷俊明, 南昌平, 高橋和久, 丸田哲郎, 赤澤努, 守 屋秀繋, 中田好則, 高相晶士, 井上雅俊, 磯辺啓二郎 :
Dynamic Breathing MRI を用いた特発性側彎症患者にお ける呼吸運動の解析, 脊柱変形, 8(1), 31-35, (2003).

8) Tokuda, J., Schmitt, M., Sun, Y., Patz, S., Tang, Y., Mountford, C.E., Hata, N., Wald, L.L. and Hatabu, H. : Lung motion and volume measurement by dynamic 3D MRI using a 128-channel receiver coil, Acad Radiol, 16(1), 22-27, (2009).

9) Toledo, N.S., Kodaira, S.K., Massarollo, P.C., Pereira, O.I. and Mies, S. : Right hemidiaphragmatic mobility: assessment with US measurement of craniocaudal displacement of left branches of portal vein, Radiology, 228(2), 389-394, (2003).

10) Yamaguti, W.P., Paulin, E., Shibao, S., Kodaira, S., Chammas, M.C. and Carvalho, C.R. : Ultrasound evaluation of diaphragmatic mobility in different postures in healthy subjects. J Bras Pneumol, 33(4), 407-413, (2007).

11) Epelman, M., Navarro, O.M., Daneman, A. and Miller, S.F. : M-mode sonography of diaphragmatic motion: description of technique and experience in 278 pediatric patients, Pediatr Radiol, 35(7), 661-667, (2005).

12) Kantarci, F., Mihmanli, I., Demirel, M.K., Harmanci, K., Akman, C., Aydogan, F., Mihmanli, A. and Uysal, O. : Normal diaphragmatic motion and the effects of body composition: determination with M-mode sonography, J Ultrasound Med, 23(2), 255-260, (2004).

13) Boussuges, A., Gole, Y. and Blanc, P. : Diaphragmatic motion studied by m-mode ultrasonography: methods, reproducibility, and normal values, Chest, 135(2), 391-400, (2008)

14) Cohen, E., Mier, A., Heywood, P., Murphy, K., Boultbee, J. and Guz, A. : Diaphragmatic movement in hemiplegic patients measured by ultrasonography, Thorax, 49(9), 890895, (1994).

15) Ayoub, J., Cohendy, R., Prioux, J., Ahmaidi, S., Bourgeois, J.M., Dauzat, M., Ramonatxo, M. and Préfaut, C. : Diaphragm movement before and after cholecystectomy: a sonographic study, Anesth Analg, 92(3), 755-761, (2001).

16) Lloyd, T., Tang, Y.M., Benson, M.D. and King, S. : Diaphragmatic paralysis: the use of $\mathrm{M}$ mode ultrasound for diagnosis in adults, Spinal Cord, 44(8), 505-508, (2006).

17) 牛木辰男, 小林弘祐, 他: カラ一図解 人体の正常構造 と機能 I 呼吸器, 66-67, 日本医事新報社, (2005).

18) 野村嶬: 標準理学療法学・作業療法学 専門基礎分野解 剖学, 115-118, 258-260, 医学書院, (2004).

19) 中村隆一, 斉藤宏 : 基礎運動学 第 6 版, 274-279, 医歯 薬出版株式会社, (2006). 


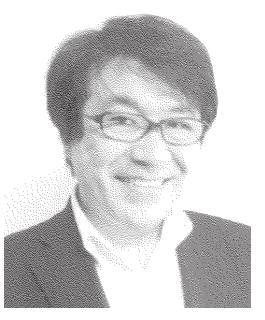

中 徹（なかとおる）

1954 年生. 東京農工大学農学部卒 業後, 東京都立府中リハビリテーショ ン専門学校卒業. 理学療法士. 鈴鹿医 療科学大学保健衛生学部理学療法学科, 同大学院医療科学研究科教授. 専門は こども・発達障害の理学療法の臨床お よび教育と研究. 日本理学療法士協会神経理学療法研究部 会運営委員. 同協会「理学療法診療ガイドライン第 1 版」 脳性まひ班班長. 発達に障害を持つ方の生活改善の視点か ら，評価・介入方法について研究を行っている. 